\title{
WEED CONTROL IN HORTICULTURAL CROPS
}

\author{
By D. W. McCALLUM, Department of Agriculture, Blenheim
}

\section{SUMMARY}

WEEDS in the various horticultural crops grown in Marlborough are discussed and particular reference is made to the weed problems associated with vegetable and vegetable seed crops. Results of trials on these crops are given.

Most of the trials described in this paper were carried out in the Blenheim and Seddon areas. Both districts have an annual rainfall of about 25 in., with rather more than half of the total falling in the winter months. The soil types range from sandy to silt loams.

There are four main phases of commercial horticulture in Marlborough: Orchard, nursery, market gardening, and vegetable and flower seed growing.

In orchard work weeds are controlled by mechanical cultivation and hand grubbing around the trees, or by the more recently developed practice of sowing the orchard down in permanent pasture and mowing regularly during the growing season. Twitch (Agropyron repens) is sometimes a nuisance around the trees, but the normal practice of digging around the butts each spring prevents the weed from becoming too aggressive.

There is probably scope for the use of weedkillers in nursery work, but with the wide range of plants there would undoubtedly be variations in susceptibility to damage from materials which may be used.

There is a weed problem in commercial vegetable growing and there is no doubt that in many cases the time spent in cultivation to remove weeds narrows the margin between an economic and an uneconomic crop. Quite a formidable list of weeds which are a problem could be drawn up, but the six worst are probably:-

Fat-hen (Chenopodium album) Winter grass (Poa annua)

Red root (Amaranthus retroflexus) Speedwell (Veronica agrestis)

Chickweed (Stellaria media) Wireweed (Polygonum aviculare)

The weed problem is further complicated on small market gardens because there is little opportunity for fallowing land before a crop goes in. This may appear to be bad husbandry, but on the 5- to 10-acre market garden intensive cropping is necessary to provide an economic living. The answer to the weed problem of the future may well lie in larger holdings which can support more mechanisation and more spelling of the land, but such areas are not easy to come by and anything which can be done to reduce the cost of production by the use of weedkillers will materially assist the market gardener.

Vegetable seed crops present similar problems to vegetables grown for markets before the emergence of flower stalks. In biennial crops such as the brassicas, carrots (Daucus carota), parsnips (Pastinicum sativum), and onions (Allium cepa) cultivation once the flower stalks have emerged and met across the rows is possible only on hands and knees and even then not without possibility of damage to the crop. The flower stalks of most crops are top-heavy and brittle. This period when cultivation is so difficult lasts for 3 to 4 months over the late spring and early summer when fat-hen, red root, and cornbind (Polygonum convolvulus) are most vigorous. The low-growing weeds are not so important. With tall weeds much seed can be lost as the wind brushes the seed heads against the weeds, and where cornbind is bad the weight of the weed frequently pulls the seed head down 
with consequent difficulty in harvesting and possible loss of seed. In onion seed crops cornbind is an additional problem in that the seed matures at about the same time as the onion seed and is difficult to dress out. The seed of black nightshade (Solanum nigrum) causes losses in white-seeded bean crops through staining of the seed when threshing. This can be avoided by stacking the beans until the nightshade seed dries out, but the production costs are increased accordingly.

Following pilot trials in 1952 with a number of weedkillers two were selected as showing the most promise in vegetables. These materials were monuron and CIPC, to both of which there seemed to be a fair degree of tolerance among some vegetables and which provided satisfactory control of weeds over some months.

Asparagus (Asparagus officinale): Monuron at $1 \mathrm{lb}$. or $2 \mathrm{lb}$, per acre has become established commercial practice on a number of holdings. Trials have been carried out at Levin Research Station and no reduction in yield has been recorded from rates as high as 10lb. per acre. Applied in the early spring just before the emergence of the spears good weed control has been obtained through the harvest period and well on into the period of vigorous fern growth. At this stage weeds are not usually of much importance to the crop. On the sandy loams around Blenheim $1 \mathrm{lb}$. of monuron is ample for the harvest period and our recommendation is $11 \mathrm{~b}$. before the emergence of the spears, followed by a further 11b. after harvesting ceases, if considered necessary.

Beetroot (Beta vulgaris): Only one pre-emergence trial has been laid down with this crop and monuron at $2 \mathrm{lb}$. per acre gave good results. CIPC at both $4 \mathrm{lb}$. and $81 \mathrm{~b}$. significantly reduced emergence. The trial area was flooded a few weeks after the trial was laid down and this undoubtedly affected the emergence of the seed on all plots. Further work will be desirable before positive recommendations can be made.

Savoy cabbage (Brassica oleracea): Reducing weed competition to a minimum for a period of 6 to 8 weeks from sowing to planting out assists in obtaining a better-quality plant. Monuron as low as $\frac{1}{2} \mathrm{lb}$. per acre completely prevented cabbage emergence, but TCA at $201 \mathrm{~b}$. gave adequate control of all weeds for the required period.

Carrots (Daucus carota): CIPC has not affected emergence at either $4 \mathrm{lb}$. or $8 \mathrm{lb}$. per acre. Unfortunately this chemical does not control fat-hen or red root adequately. These weeds are reduced in quantity and grow with less vigour, but they still appear in sufficient numbers to overwhelm the crop if further steps are not taken. After quite extensive trials it has been found that hand work can be reduced with a pre-emergence spray of $4 \mathrm{lb}$. of CIPC per acre, followed when necessary by power kerosene to kill such fat-hen and red root as do emerge. On some carrot areas cornbind can be a problem and CIPC has given full control of this weed for some months. Crops have been observed where CIPC has caused a slight yellowing and stunting of the carrot tops, but there has been no evidence to suggest a reduction in yield.

Onions (Allium cepa): Monuron and CIPC have been used both preand post-emergence on commercial onion crops and in trials. In all cases monuron has depressed bulb yields appreciably. CIPC has not affected the bulbs, but again the relatively poor control of fat-hen and red root make it necessary for a contact weedkiller to be used. Sulphuric acid is cheap and, with reasonable precautions, easy to apply and CIPC at $4 \mathrm{lb}$. per acre followed by sulphuric acid when necessary have controlled weeds for about 3 months. On autumn-sown onions CIPC has been particularly successful in controlling Poa annua for the entire winter period. This weed is troublesome to clear and CIPC at $4 \mathrm{lb}$. per acre at a cost of under $£ 6$ is well justified. 
Garlic (Allium sativum): Only one trial has been laid down with this crop and both monuron and CIPC reduced the yield. The crop reduction with monuron at $2 \mathrm{lb}$. per acre was significant at the 1 per cent. level.

Onions for seed: Monuron has done an outstanding job with this crop either as a pre- or post-emergence spray. CIPC gave adequate weed control, but the onion flower stems were stunted and small bulbs were control, but the onion flower stems were stunted and smations are possible with this crop:-

1. Monuron at $2 \mathrm{lb}$. per acre applied pre-emergence.

2. Monuron at $1 \mathrm{lb}$. per acre applied just when flower heads are emerging, but before they meet across the rows.

General: A screening trial with a range of crops indicated the tolerances shown.

\begin{tabular}{lccc}
\hline & Monuron, 2lb. & CIPC, 6lb. & TCA, 20lb. \\
\hline Sweetcorn (Zea mays) & $\mathrm{t}$ & $\mathrm{t}$ & $\mathrm{d}$ \\
Broad bean (Vicia faba) & $\mathrm{t}$ & $\mathrm{t}$ & $\mathrm{d}$ \\
Pole beans (Phaseolus vulgaris) & $\mathrm{t}$ & $\mathrm{t}$ & $\mathrm{d}$ \\
Peas (Pisum sativum) & $\mathrm{t}$ & $\mathrm{t}$ & $\mathrm{d}$ \\
Radish (Raphanus sativus) & $\mathrm{d}$ & $\mathrm{t}$ & $\mathrm{t}$ \\
Turnip (Brassica spp) & $\mathrm{d}$ & $\mathrm{d}$ & $\mathrm{t}$ \\
$\mathrm{d}=$ damage & & & \\
$\mathrm{t}=$ tolerant & &
\end{tabular}

This trial was intended only to provide a lead for further experimental work. No crop was carried through to maturity.

\section{CONCLUSION}

Our knowledge of weed control in vegetable crops is still limited and a great deal more experimental work will have to be carried out and possibly new chemicals developed before we can provide all the answers. possibly new chemicals developed before appears to be the ideal herbicide, but the stability of this material in the soil must be borne in mind. On two wo ats and barley following some 3 to 4 months after the application of the weedkiller have germinated and then died off. Though no work has garden crops such as the brassicas would also suffer.

This Conference has contributed greatly over the years to the over-all knowledge of weed control on farms. Though weeds in vegetable crops have also been discussed from time to time, much remains to be learnt.

\section{DISCUSSION}

Q.-Can dalapon be used successfully for the control of couch (Agropyron repens) in asparagus?

A. - Yes, provided the spray does reach the soil when the asparagus is growing actively.

Q.-Is CIPC always satisfactory as a pre-emergence treatment for onions?

A.- No, the onions should be established before CIPC is applied and should be supplemented by sulphuric acid treatments or hand weeding.

Q.-Which material has been most successful for weed control in onion seed crops-CIPC or monuron?

A.-Monuron has given the best results.

Comment: In a replicated trial at Rukuhia Soil Research Station monuron significantly outyielded control plots and was also better than CIPC. 